\title{
Influence of Metabolic Control on Growth in Homocystinuria due to Cystathionine B-Synthase Deficiency
}

\author{
ALI KEMAL TOPALOGLU, CLAUDE SANSARICQ, AND SELMA E. SNYDERMAN
}

Department of Human Genetics, Mount Sinai Medical Center, New York, New York 10029, U.S.A.

\begin{abstract}
The etiology of the tall stature almost invariably seen in homocystinuric patients is not known. The effect of metabolic control and the role of the GH-IGF system on growth were investigated in 10 patients with homocystinuria. There was a direct correlation between the plasma free homocyst(e)ine and growth velocity SD scores in 18 patient years $(r, 0.46 ; p<0.05)$. Plasma 2-y cumulative free homocyst(e)ine and height SD scores were directly correlated $(r, 0.82 ; p<0.01)$. Growth velocity SD scores were lower in patients with optimal metabolic control than in those with poorer control $(-0.10 \pm 0.65$ versus $0.95 \pm 0.68$, $p<0.01)$. Height SD scores were also lower in the optimally controlled group $(-0.01 \pm 0.81$ versus $1.73 \pm 0.88, p<0.05)$. $\mathrm{GH}$ and $\mathrm{GH}-$ related peptides did not deviate significantly from the reference ranges. These findings suggest that overgrowth is
\end{abstract}

\section{ABSTRACT}

directly mediated by homocysteine, that the GH-IGF axis is not involved, and that it may be prevented by optimal metabolic control. (Pediatr Res 49: 796-798, 2001)

$\quad$ Abbreviations
HC, homocyst(e)ine
HCA, homocysteic acid
HSDS, height SD scores
GV, growth velocity
GVSDS, growth velocity SD scores
IGFBP-3, IGF binding protein-3
IGF-1, insulin-like growth factor-1
IGFBP-3, insulin-like growth factor binding protein-3

Homocystinuria (McKusick 236200) due to cystathionine B-synthase (EC 4.2.1.22) deficiency is an inborn error of transsulfuration metabolism. The major biochemical abnormalities include elevation of $\mathrm{HC}$ and methionine and reduction of cystine in body fluids. Clinical manifestations include dislocation of the optic lens, mental retardation, psychiatric disturbances, thromboembolic phenomena, malar flush, livido reticularis, and skeletal abnormalities such as osteoporosis, scoliosis, arachnodactyly, and tall stature (1). It has been difficult to relate this wide variety of symptoms to a deficiency of a single enzyme. Thus, it has been classified as a connective tissue disorder, the result either of fibrillin damage or of impaired cross-linkage caused by complexing between aldehyde groups and HC. Although this may account for a number of the symptoms of the disease, it may not be responsible for the tall stature that has almost invariably been associated with the disease. Both HC and HCA, the sulfonic acid derivative of $\mathrm{HC}$, have been suggested as the cause of the excessive growth. One study reported that HCA increased serum somatomedin activity in rats (2), whereas another study found that it accelerated the growth of

Received October 18, 1999; accepted November 3, 2000

Correspondence and reprint requests: Selma E. Snyderman, M.D., Department of Human Genetics, Mount Sinai Medical Center, 1 Gustave L. Levy Place-Box 1497, New York, NY 10029, U.S.A.; e-mail: selma.snyderman@mssm.edu guinea pigs (3). These findings have been challenged by other studies that have implicated $\mathrm{HC}$ as the agent responsible for growth $(4,5)$. These studies have all been carried out either in animals or in cell lines derived from homocystinuric patients. However, the relationship of the growth pattern to the degree of metabolic control, as defined by the plasma $\mathrm{HC}$, has not been evaluated in homocystinuric patients.

Our interest in this excessive growth was stimulated by the observation that each of our patients diagnosed as the result of newborn screening and maintained in good metabolic control has grown at a rate similar to that of unaffected siblings, whereas patients diagnosed later in life have been excessively tall. In addition, the loss of metabolic control in several patients has precipitated a growth spurt. This led us to examine retrospectively the relationship between growth, the plasma $\mathrm{HC}$, and the GH-IGF axis.

\section{METHODS}

Subjects and methods. Five male and five female patients aged 7.9 to 18.5 y of age were included in the study. Six were diagnosed as a result of newborn screening, and the remaining four were diagnosed because of symptoms at 4 to $8 \mathrm{y}$ of age. All patients except one who was questionably responsive were pyridoxine nonresponsive. This was a retrospective study of 
patients enrolled in our clinic. Permission for treatment was obtained from parents or guardians and approval from the Board of Research Associates at the time of enrollment. The data were obtained while the patients were receiving nutritional therapy with a special formula free of methionine. The methionine requirement was provided by carefully measured natural protein. The same nutritional management was used for all patients and was supervised by a metabolic nutritionist to assure that they were provided with all the necessary nutrients in adequate amounts. None of the patients was receiving betaine.

A standard stadiometer was used to measure height. HSDS were calculated from population standards (6). Prepubertal growth and $\mathrm{HC}$ at age 5 to 7 were retrieved from the records of the three postpubertal patients; their HSDS were calculated at $7 \mathrm{y}$. GVSDS were calculated from Fels longitudinal growth study data (7).

Plasma free $\mathrm{HC}$ was determined by ion exchange column chromatography on fasting blood. Bloods were deproteinized immediately after drawing, frozen, and kept at $-70^{\circ} \mathrm{C}$ until analyzed. Mean free $\mathrm{HC}$ of control subjects in our laboratory is $1.47 \pm 2.69 \mu \mathrm{mol} / \mathrm{L}$. This is in the same range as that reported by a number of other laboratories (8).

Four to eight levels per year, at least 1 mo apart, were averaged for each subject. HC obtained at times of intercurrent infections were not included. Data for the year preceding the time of study are identified as year minus one and for the year preceding that as minus two. Cumulative $\mathrm{HC}$ values for these 2 y were also calculated. Yearly average $\mathrm{HC}, \mathrm{GV}$, cumulative $\mathrm{HC}$, and HSDS were correlated. In addition, early and latediagnosed patients and optimally and poorly controlled groups were also compared. A plasma $\mathrm{HC}$ of $11 \mu \mathrm{mol} / \mathrm{L}$ was used as the cutoff value for the latter groups. This cutoff point was based on a report of Yap and Naughten (9) who found in a study of 25 patients followed for $25 \mathrm{y}$ that those who maintained a median lifetime free $\mathrm{HC}$ less than $11 \mu \mathrm{mol} / \mathrm{L}$ did not develop the complications of this disorder.

GH was determined with a commercially available RIA kit (Diagnostic Products, Los Angeles, CA, U.S.A.). IGF-1 and IGFBP-3 were measured by a commercial laboratory (Nichols Institute, San Juan Capistrano, CA, U.S.A.). IGF-1 was deter- mined by the method of Clemmons et al. (10) and IGFBP-3 by the method of Baxter and Martin (11). These results were available in eight patients.

Correlation coefficients were calculated by Spearman's method. Optimally and poorly controlled groups were compared by the independent samples $t$ test (HSDS and GVSDS). The Mann-Whitney $U$ test was used for $\mathrm{HC}$ and cumulative $\mathrm{HC}$ because of the nonnormal distribution of these values.

\section{RESULTS}

The clinical features, growth, and $\mathrm{HC}$ data are shown in Table 1. The mean HSDS of the study population was found at $1.03 \pm$ 1.38 when compared with age and sex-matched population standards. There was a direct correlation between plasma 2-y cumulative HC levels and HSDS $(r, 0.8 .2 ; p<0.01)$. GVSDS were directly correlated with plasma $\mathrm{HC}(r, 0.46 ; p<0.05)$. When optimally and poorly metabolically controlled groups were compared, statistically significant differences were found in yearly $\mathrm{HC}$ $(2.70 \pm 3.33$ versus $30.50 \pm 16.94 \mu \mathrm{mol} / \mathrm{L}, p<0.01)$ and in $2-\mathrm{y}$ cumulative $\mathrm{HC}(3.29 \pm 4.51$ versus $34.47 \pm 15.16 \mu \mathrm{mol} / \mathrm{L}, p<$ $0.05)$. The patients with optimal control had lower HSDS $(-0.01$ \pm 0.81 versus $1.73 \pm 0.88, p<0.05)$. GVSDS were also lower in the optimally controlled group $(-0.10 \pm 0.65$ versus $0.95 \pm$ $0.68, p<0.01$ ). Those patients who were diagnosed at newborn screening had lower HSDS than those diagnosed late $(0.22 \pm 1.02$ versus $2.22 \pm 0.89, p<0.05$ ).

GH, IGF-1, and IGFBP-3 are listed in Table 2. All values were within age and sex-appropriate ranges except for a slightly low IGF-1 and IGFBP-3 in patients 4 and 9, respectively, and a high IGFBP- 3 in patient 2.

\section{DISCUSSION}

The cause of the tall stature in homocystinuric patients is controversial. McCully (3) and Clopath et al. (2) reported that $\mathrm{HCA}$, a metabolite of $\mathrm{HC}$, restored the growth of hypophysectomized rats and that serum from these animals contained somatomedin activity similar to that of control rats. They concluded that HCA acted like pituitary GH and that this explains the excessive

Table 1. Clinical features, homocyst(e)ine levels, and growth data

\begin{tabular}{|c|c|c|c|c|c|c|c|c|c|c|c|c|}
\hline \multirow[b]{3}{*}{ Patient } & \multirow[b]{3}{*}{ Sex } & \multirow{3}{*}{$\begin{array}{c}\text { Treatment } \\
\text { started }\end{array}$} & \multirow{3}{*}{$\begin{array}{l}\text { Age } \\
(\mathrm{y})\end{array}$} & \multirow{3}{*}{$\begin{array}{l}\text { Height } \\
(\mathrm{cm})\end{array}$} & \multirow[b]{3}{*}{ HSDS } & \multirow{3}{*}{$\begin{array}{c}\text { Cumulative } \\
\text { HC } \\
\text { umol/L }\end{array}$} & \multicolumn{3}{|c|}{ Year minus 1} & \multicolumn{3}{|c|}{ Year minus 2} \\
\hline & & & & & & & GV & GVSDS & $\mathrm{HC}$ & GV & GVSDS & $\mathrm{HC}$ \\
\hline & & & & & & & $\mathrm{cm} / \mathrm{y}$ & & umol/L & $\mathrm{cm} / \mathrm{y}$ & & umol/L \\
\hline 2 & $\mathrm{~F}$ & $21 \mathrm{D}$ & 7 & 125 & 0.72 & 21.7 & 6.5 & 0.25 & 19.7 & 7 & 0.31 & 24 \\
\hline 3 & $\mathrm{~F}$ & $5 \mathrm{Y}$ & 8.5 & 144 & 2.4 & 51.2 & 7 & 1.32 & 46 & 6 & 0.3 & 58.60 \\
\hline 4 & $\mathrm{~F}$ & $8 Y$ & 9 & 153 & 3.38 & & 7 & 1.14 & 22.6 & & & \\
\hline 7 & M & $47 \mathrm{D}$ & 9.8 & 138 & 0.27 & 4.1 & 4 & -1 & 5.7 & 6.5 & 0.64 & 2.3 \\
\hline $8^{*}$ & M & $18 \mathrm{D}$ & 18.5 & 118 & 0.56 & 0.1 & 5.7 & -0.55 & 0.1 & 6.5 & 0.07 & 0.1 \\
\hline $9 *$ & M & $5 \mathrm{Y}$ & 16 & 128 & 1.28 & 1.3 & 6.5 & 0.13 & 1.4 & 5 & -1.19 & 1.2 \\
\hline $10^{*}$ & $\mathrm{~F}$ & $4 \mathrm{D}$ & 12.3 & 116 & -0.61 & 0.1 & 6 & -0.14 & 0.1 & 7.5 & 0.75 & 0.1 \\
\hline
\end{tabular}

$\mathrm{D}=$ days.

$\mathrm{Y}=$ years.

* Height and HSDS at $7 \mathrm{y}$, cumulative HC, 5-7 y.

Year minus 1 and 2 calculated from $7 \mathrm{y}$. 
Table 2. GH-IGF Axis

\begin{tabular}{clcc}
\hline $\begin{array}{c}\text { Patient } \\
\text { No. }\end{array}$ & GH ng/mL & IGF-1 ng/mL & $\begin{array}{c}\text { IGFBP-3 } \\
\mathrm{mg} / \mathrm{L}\end{array}$ \\
\hline 1 & $2.8(0-8)^{*}$ & $393(109-485)^{*}$ & $3.1(1.5-4.3)^{*}$ \\
2 & $2.1(0-8)$ & $220(128-470)$ & $4.59(0.9-4.1)$ \\
3 & $7.7(0-8)$ & $205(128-470)$ & $3.5(1.5-4.3)$ \\
4 & $0.5(0-8)$ & $94(128-470)$ & $1.9(1.5-4.3)$ \\
6 & $1.7(0-8)$ & $149(128-470)$ & $3.5(1.5-4.3)$ \\
7 & $0.13(0-8)$ & $220(109-485)$ & $3.5(1.5-4.3)$ \\
8 & $0.6(0-8)$ & $239(182-780)$ & $2.9(2.0-4.0)$ \\
9 & $2.1(0-8)$ & $364(182-780)$ & $2.0(2.2-4.2)$ \\
\hline
\end{tabular}

* Reference range (Ref. 20).

growth of homocystinuric patients. However, their results could not be reproduced by Bohnet (12) or Chrzanowska et al. (4). Marked elevation in IGF-1 or IGFBP-3 was not observed in the present study. Because the distribution of these hormones is skewed in the normal population, $z$ scores could not be calculated and correlation studies could not be performed. However, if there had been a GH-like effect of HC or any of its derivatives, IGF-1 and IGFBP-3 should have been altered because these peptides reflect the status of GH (13).

On the other hand, an association between increased growth and $\mathrm{HC}$ was found in the present study. There was a significant direct correlation between yearly GVSDS and plasma free HC. In addition, the growth velocities of the optimally metabolically controlled group were significantly less than those of the poorly controlled group. Because attained height is the result of cumulative effects, it would have been preferable to study the relationship between lifetime HC and HSDS. It was not possible to do this because four patients were diagnosed late. Instead, 2-y cumulative $\mathrm{HC}$ were used and showed a significant direct correlation with HSDS. There was also a significant difference between the cumulative $\mathrm{HC}$ of optimally versus poorly controlled and of early versus late-diagnosed patients and HSDS.

The differences in growth between these two groups of patients cannot be attributed to nutritional factors. Both groups received more than adequate intake of protein, calories, and all other nutrients. This intake was carefully supervised by a metabolic nutritionist. The plasma methionine, an essential amino acid, the precursor of $\mathrm{HC}$, was in the normal range or slightly above this in the well-controlled children and higher in the poorly controlled. It is quite unlikely that this elevated methionine could have caused the greater growth; patients with methionine adenosyltransferase deficiency with greater elevation of methionine are symptom free (1). The poorly controlled patients did take more protein than prescribed. However, there is no information that the intake of more than adequate protein has an effect on growth. The well-controlled children grew normally.

There are two other clinical conditions in which there is elevation of $\mathrm{HC}$, but neither is associated with increased height. Cobalamin C-disease patients tend to have failure to thrive as a result of the associated methylmalonic acidemia. Patients with methylenetetrahydrofolate reductase deficiency have elevation of $\mathrm{HC}$; this has been referred to as "moderately elevated or not more than $25 \%$ above normal" (14). Plasma HC in untreated or poorly controlled homocystinuric patients is much higher. This suggests that growth is affected only when the $\mathrm{HC}$ is greatly increased and, thus, supports the findings of this report.

A direct effect of $\mathrm{HC}$ on cell proliferation has been demonstrated in several studies. Sulfhydryl groups were shown to be involved in cell division of simple organisms (15). HC increased DNA synthesis and cell proliferation of rat aortic smooth muscle cells (16). In addition, aortic cyclin-dependent kinase was high in HC-fed rats (17). Recently, plasma cyclindependent kinase levels were found to be high and significantly correlated with $\mathrm{HC}$ in a group of 10 homocystinuric patients. However, these investigators did not relate this data to the height or rate of growth of their patients (5). Because this enzyme has a central role in coordinating cell division and integrating growth-regulating signals $(18,19)$, this may provide an explanation for the tall stature of untreated homocystinuric patients. There may be other direct effects of $\mathrm{HC}$ on growth such as the stimulation of chondrocytes, but this has not yet been investigated. The present study demonstrates a direct effect of $\mathrm{HC}$ on human growth; the exact mode of its action still needs to be determined.

Acknowledgment. The authors thank Dr. Ali S. Calikoglu of the University of North Carolina for his helpful advice.

\section{REFERENCES}

1. Mudd SH, Levy HL, Schoolboy F 1995 Disorders of transsulfuration. In: Scriver CR, Beaudet AL, Sly WS, Valle D (eds) The Metabolic and Molecular Bases of Inherited Disease. McGraw Hill, New York, pp 1279-1327

2. Clopath P, Smith VC, McCully KS 1976 Growth promotion by homocysteic acid. Science 192:372-374

3. McCully KS 1975 Growth disorders and homocysteine metabolism. Ann Clin Lab Sci 5:147-152

4. Chrzanowska BL, Nitzan M, Phillips LS, Schulman JD 1979 Homocysteic acid: an examination of its possible growth hormone-like activity. Metabolism 28:80-83

5. Fritzer-Szekeres M, Blom HJ, Boers GH, Szekeres TH, Lubec B 1998 Growth promotion by homocysteine but not by homocysteic acid: a role for excessive growth in homocystinuria or proliferation in hyperhomocysteinemia. Biochim Biophys Acta 1407:1-6

6. Hamill PV, Drizd TA, Johnson CL, Reed RB, Roche AF 1977 NCHS growth curves for children birth-18 years. United States. Vital Health Stat 165:1-74

7. Baumgartner RN, Roche AF, Himes JH 1986 Incremental growth tables: supplementary to previously published charts. Am J Clin Nutr 43:711-722

8. Ueland PM, Refsum H, Stabler SP, Malinow MR, Anderson A, Allen RH 1993 Total homocysteine in plasma or serum: methods and clinical applications. Clin Chem 39:1764-1779

9. Yap S, Naughten E 1998 Homocystinuria due to cystathionine B-synthase deficiency in Ireland: 25 years experience of a newborn screened and treated population with reference to clinical outcome and biochemical control. J Inher Met Dis 21:738-747

10. Clemmons DR, Van Wyk JJ, Ridgeway EC, Kliman B, Kjellberg RN, Underwood LE 1979 Evaluation of acromegaly by radioimmunoassay of somatomedin-C. N Engl J Med 30:1138-1142

11. Baxter RC, Martin JL 1986 Radioimmunoassay of growth hormone-dependent insulin-like growth factor binding protein in human plasma. J Clin Invest 78:1504-1512

12. Bohnet HG 1976 Lack of a direct effect of homocysteic acid on growth hormone prolactin receptors. Endokrinologie 68:355-358

13. Blum WF, Albertsson-Wikland K, Rosberg S, Ranke MB 1993 Serum levels of insulin-like growth factor (IGF-I) and IGF-binding-protein-3 reflect spontaneous growth hormone secretion. J Clin Endocrinol Metab 76:1610-1616

14. Bailey LB, Gregory III JF 1999 Polymorphisms of methylenetetrahydrofolate reductase and other enzymes: metabolic significance, risks, and impact on folate requirement. J Nutr 129:919-922

15. Stern H 1956 Sulfhydryl groups and cell division. Science 124:1292-1293

16. Tsai JC, Perrella MA, Yoshizumi M, Hsieh CM, Haber E, Schlegel R, Lee ME 1994 Promotion of vascular smooth muscle cell growth by homocysteine: a link to atherosclerosis. Proc Natl Acad Sci USA 91:6369-6373

17. Lubec B, Arbeiter K, Hoeger H, Lubec G 1996 Increased cyclin-dependent kinase in aortic tissue of rats fed homocysteine. Thromb Haemost 75:542-545

18. Lucas JJ, Terada N, Szepesi A, Gelfand EW 1992 Regulation of synthesis of p34 $(\mathrm{cdc} 2)$ and its homologues and their relationship to $\mathrm{p} 110(\mathrm{Rb})$ phosphorylation during cell cycle progression of normal human T cells. J Immunol 148:1804-1811

19. Dutt A, Stillman B 1992 cdc2 family kinases phosphorylate a human cell DNA replication factor, RPA, and activate DNA replication. EMBO J 11:2189-2199

20. Blizzard RM, Johanson A 1994 Disorders of growth. In: Kappy MS, Blizzard RM, Migeon CJ (eds) The Diagnosis and Treatment of Endocrine Disorders in Childhood and Adolescence. Charles C. Thomas, Springfield, IL, pp 383-456 